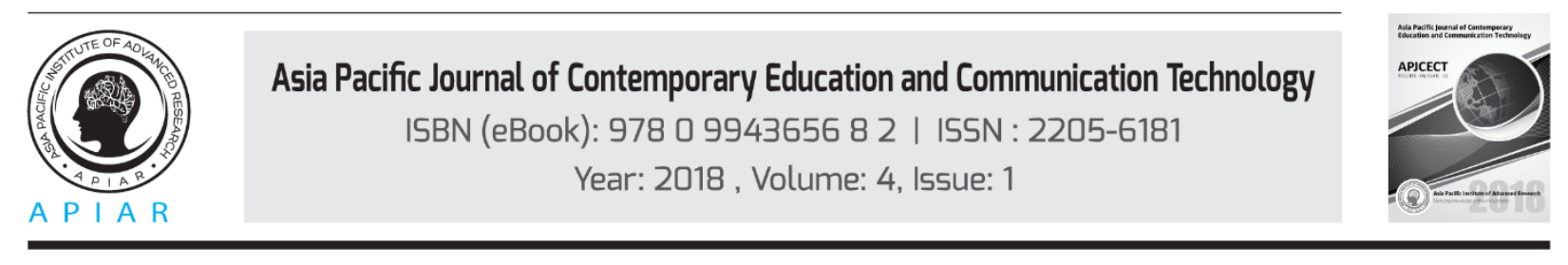

\title{
TANGRAM INTERACTIVE GAME (TIG): INSTRUCTIONALMEDIA IN LEARNING GEOMETRY
}

\author{
Trimurtini a Farid Ahmadi ${ }^{b}$ \\ ab Universitas Negeri Semarang, Semarang, Indonesia \\ Corresponding email: trimurtinipgsd@mail.unnes.ac.id
}

\begin{abstract}
Instructional media is required in learning mathematics, especially in learning geometry. Tangram is one of media in geometry. But, the use of tangram is often overlooked because it is considered less attractive. The purpose of this research and development is to develop a media in learning geometry which is Tangram Interactive Game (TIG) to enhance conceptual understanding in plane geometry. The Tangram Interactive Game (TIG) media was developed based on the review of literature and experts' interview. Then, it was tested by 35 students of Elementary School Teacher Education Department, followed by the approval from the experts. Data analysis indicated that there was a statistical difference between pre and post test scores at .05 level significant. The result of this study showed that the Tangram Interactive Game (TIG) media consist of four components as detailed in the article.
\end{abstract}

Keywords: Tangram, Interactive Game, Media in Learning Geometry, Learning Mathematics.

\section{Introduction}

Education quality is one of the elements in the management paradigm of higher education in Indonesia. This implies that education should be relevant to the needs of the community and the stakeholders, as well as to the academic atmosphere in the education management. From the lecturers' side, the quality can be seen from how optimal the lecturer is able to facilitate the learning process for students. Meanwhile, from the quality curriculum side, the quality can be seen from how relevant the curriculum to provide various learning stimulus and facilities (Department of National Education, 2004, p. 6).

To maintain the education quality in the Department of Primary School Teacher Education, Faculty of Teacher Training and Education, Universitas Negeri Semarang (UNNES), one of the measures should be taken is that every year, Department of Primary School Teacher Education shall adapt the current development and needs for curriculum and teaching administration. Even, in the academic year of 2014/2015, Department of Primary School Teacher Education carried out several curriculum adjustments that were quite significant by reviewing the subject names and then adjusted it with Presidential Regulation No. 8 of 2012 on Indonesian National Qualification Framework and Regulation of the Ministry of Education and Culture No. 14 of 2014 on National Academic Standards for Higher Education.

In addition, it is necessary to make the adjustment of teaching materials in accordance with the needs and development of science and technology along with the renewal of teaching administration. This is necessary because lecturers are deemed to have limitation in accessing 
new information that may enable them to know the latest development in their fields. Moreover, the students also consider the teaching material as too theoretical; lack of contextual examples (Department of National Education, 2004, p. 3)

Mathematics course in the department of Primary School Teacher Education still needs improvement, from the theoretical to the contextual, especially in the learning courses related to mathematic learning in elementary schools; number and data processing, geometry and measurement learning, mathematic learning improvement. By considering the learning theories that already exist or being developed, and pay attention to the various utilization of appropriate instructional media, so it is expected that the material becomes more contextual and operational when it is going to be learnt and used in mathematics learning.

Geometry is often used in real life as it is one of the most important parts in mathematics (Topas, 2011). However, geometry and measurement learning still needs to have more attention in the department of Primary School Teacher Education because the students' ability in mastering geometric concepts are still low. Students of the Department of Primary School Teacher Education taking the course of geometry and measurement learning in the year of 2015 were given diagnostic tests on the mastery of the concept of plane geometry and measurement. The results showed that $62 \%$ of students had not mastered some basic concepts of plane geometry (point, line, angle, curve), $78 \%$ of students had not mastered the concept of triangle, $60 \%$ of students had not mastered the concept of rectangular, and $75 \%$ of students had not mastered the concept of measurement on a plane shape. Another research was also conducted for prospective teachers of elementary schools (Zilkova et al, 2012) and it showed the cause why students did not master the material of plane geometry. It was because the students did not know the forms and properties of plane shapes properly.

Learning the meaning of abstract geometric concept is related to the level of student's thinking development, so it is necessary to adjust the development of material with that level. The learning theory proposed by Van Hiele (Pitadjeng, 2015) shows that there are three main elements in the geometric learning that are time, material and method applied. Therefore, five learning stages offered by Van Hiele for geometric learning should be introduced to students of Primary School Teacher Education who still find difficulty in mastering geometric concept and later the students of Primary School Teacher Education will teach geometry to elementary students.

Tangram game can be used to assist in understanding the shape of plane geometry (Rusefrendi, 1992). Tangram is a game of ancient Chinese; it can be used as an instructional media in plane geometry. Tangram games have to be packaged in an interactive form, so it will look attractive and can be studied by students independently.

Based on the description of the research background above, the research problems are found as follows:

1. How does the development of interactive tangram game media development in the plane geometry learning?

2. How does the result of valid interactive tangram game media development in the plane geometry learning for students of Department of Primary School Teacher Education, Faculty of Teaching Training and Education, UNNES? 


\section{Research Method}

This research is categorized as educational research and developments. Development means interactive tangram game media development in learning plane geometry and Van Hiele theory based measurement for students of Department of Primary School Teacher Education, Faculty of Teaching Training and Education, Semarang State University.

The development of instructional media is part of the development of teaching administration, so the researchers used the development model proposed by Thiagarajan, Sammel and Sammel (Rachman, 2015, p. 358) known as Four-D Model (Model 4-D), which are defining, design, development and dissemination. Because the focus in this study is to generate instructional media, this research ends in the dissemination of Tangram Interactive Game media for the learning of plane geometry and measurement.

\section{Finding and Discussion}

Research activity on the development of interactive tangram media had been performed for 6 months. Here are the details of the activity performance:

1. Defining stage: Included the initial-final analysis of the problems encountered in the study, which was media development for students of Department of Primary School Teacher Education; Concept analysis of developed interactive tangram game media; Analysis of material adapted in developed interactive tangram game media; analysis of types of game that can be developed in interactive tangram game media.

2. Design stage: Included the preparation of templates for interactive tangram game media; Literature study to enrich material in interactive tangram game media; Selection of appropriate materials for interactive tangram game media intended for students of Department of Primary School Teacher Education; Selection of interactive tangram game media formats with flash software; the creation of initial design as draft 1

3. Development stage: included the achievement test trial, expert validation, limited trial, field trials.

\section{a. Expert Validation}

The result from draft 1 was consulted to the material expert of math education. There were several input obtained from discussion expert and material expert, which were: the form of exercise, adjustment of material content with the national curriculum that has been applied. Draft II was obtained from the results of this revision. Then, Draft II was consulted with media expert, inputs from media expert were the preparation of menus to have more effective use of word, "back" or "home" menu should be presented in every slide, color selection and artistic image placement. Based on these advices from the media expert, then draft II was revised and resulted in draft III. After the Tangram Interactive Game media was improved, material expert and media expert assessed interactive tangram game media by using the assessment instrument. Expert validation results can be summarized as in table 1.

Table 1: Expert validation to asses developed tangram interactive game media

\begin{tabular}{llcc}
\hline No & \multicolumn{1}{c}{ Indicator } & $\begin{array}{c}\text { The } \\
\text { assessment } \\
\text { of material } \\
\text { expert }\end{array}$ & $\begin{array}{c}\text { The assessment } \\
\text { of media expert }\end{array}$ \\
\hline $\mathbf{1}$ & $\begin{array}{l}\text { The completion of media content } \\
\text { (material, exercise, task) }\end{array}$ & 4 & 4 \\
\hline $\mathbf{2}$ & $\begin{array}{l}\text { The conformity of media content with } \\
\text { applicable curriculum in Department of } \\
\text { Primary School Teacher Education }\end{array}$ & 4 & 1 \\
\hline
\end{tabular}

Asia Pacific Institute of Advanced Research (APIAR)

10.25275/apjcectv4i1edu7 


\begin{tabular}{llcc}
\hline No & \multicolumn{1}{c}{ Indicator } & $\begin{array}{c}\text { The } \\
\text { assessment } \\
\text { of material } \\
\text { expert }\end{array}$ & $\begin{array}{c}\text { The assessment } \\
\text { of media expert }\end{array}$ \\
\hline 3 & $\begin{array}{l}\text { The conformity of media content with Van } \\
\text { Hiele Theory }\end{array}$ & 3 & 4 \\
\hline 4 & $\begin{array}{l}\text { Interactive level of media that has been } \\
\text { made (exercises) }\end{array}$ & 3 & 2 \\
\hline 5 & $\begin{array}{l}\text { Display aspects (font, picture, animation, } \\
\text { sound) }\end{array}$ & 4 & 3 \\
\hline 6 & $\begin{array}{l}\text { Inspirational aspects (elements of novelty, } \\
\text { usefulness, trigger students' creativity) }\end{array}$ & 4 & 2.5 \\
\hline & Average & 3.67 & $62.5 \%$ \\
\hline & Percentage & $91.67 \%$ & 1 \\
\hline
\end{tabular}

Assessment carried out by material expert and media expert on Interactive tangram game media can be seen in detail in table.1.It describes that both experts gave the average score of 3.09 and the percentage was $77.09 \%$. Consequently, it can be concluded that interactive tangram game media is categorized as good, it is proven on the six assessment aspects on the conformity of media content with curriculum in Department of Primary School Teacher Education and Elementary school as well as Van Hiele theory. In addition, there are also display aspects, inspirational aspect, and interactive level.

\section{b. Achievement Test Trial Andlimited Trial}

Limited trials had been carried out on 6 study groups. On the same occasion, trial was also conducted on problems of learning outcomes that will be used in an extensive trial. The problem was found in limited trial, there was error in the answer key. Therefore, arouse comments showing that interactivity of interactive tangram game media was less precise. Then, for the display of interactive tangram game media on 10 inch display laptop and 11 inch above, it was found that there was a difference in the unit placement. After that, revision was conducted again on the interactive tangram game media and lastly obtained final interactive tangram game media. From pre-test and post-test instrumental trials, we obtained the validity of problem of 0.61 and 0.64 for two questions made, so both problems were categorized as high validity. While the reliability showed 0.423 , it meant that it had average reliability. Therefore, from this result, pre-test and post-test instruments are suitable for the use in field trials.

\section{c. Field Trial}

Field trialhad been carried out on 3 study groups with 35 students. The lecture began with the provision of pre-test to find out the students' early skills. The pre-test results showed an average of 10.3, the highest score was 50, while the lowest score was 0 . This indicated the student's early ability was still low. After the pretest, the lecture was continued with preliminary activities, followed by core activities. In the core activities, students discussed in groups to learn materials by using interactive tangram game media in each laptop in group. In addition, paper foldings, scissors and glue as the equipment in the implementation of lectures were also provided. After the group discussion concerning materials and tasks presented in interactive tangram game media, each group went to another group to find another groups' result. Then, the Lecturer arranged a classical discussion about the difficulties and obstacles of students in learning geometry and measurement and its instruction in elementary school. Next, the students were given the task to develop Student Worksheet for elementary students that conformed to selected basic competence. Student Worksheet results were then assessed to determine the success of interactive tangram game media in developing inspirational 
character. The results of the assessment found a description of the inspirational characters that were expected to appear in students. It can be seen in table 2.

Table2:Instrument to asses Student Worksheet made by Students for the learning of basic geometry in Elementary School

\begin{tabular}{llcc}
\hline No & \multicolumn{1}{c}{ Indicator } & $\begin{array}{c}\text { Assessmen } \\
\text { t average }\end{array}$ & Category \\
\hline $\mathbf{1}$ & $\begin{array}{l}\text { Conformity of Basic Competent with indicators } \\
\text { developed in Worksheet }\end{array}$ & 3,8 & Excellent \\
\hline $\mathbf{2}$ & $\begin{array}{l}\text { Conformity of Basic Competent with material } \\
\text { developed in Worksheet }\end{array}$ & 2,7 & Good \\
\hline 3 & $\begin{array}{l}\text { Make students to be active (involving hand } \\
\text { activities/psychomotor and cognitive) }\end{array}$ & 3,1 & Good \\
\hline 4 & $\begin{array}{l}\text { Procedures of students activities in Worksheet are } \\
\text { coherent }\end{array}$ & 2,5 & Average \\
\hline 5 & Student creativity in developing worksheet & 2,1 & Average \\
\hline & Averages & 2,84 & Good \\
\hline
\end{tabular}

From the five indicators of observation on the inspirational character contained in the tasks of Student Worksheet produced by the students, it obtained an average of 2.84 and was included in the "good" category. Consequently, it can be concluded that interactive tangram game media was able to inspire students in finishing the task properly. So, the inspirational character that was expected to appear in the students can be seen from the quality of the Student Worksheet produced by them. It was seen from the material accuracy, the coherent action step and it was also able to invite the students to be active in cognitive and psychomotor as well as to encourage students' creativity. The five indicators were in the category of average to excellent, so it can be considered to have good category.

At the end of the lecture, students were given post-test. The post-test working time was the same as pre-test working time (15 minutes), therefore, it obtained the average score of 48 with the highest score of 80 and the lowest score of 10 . The results of the field test showed that the developed integrative tangram game media was already used in the learning process and it obtained good results in the building of Inspirational character. In addition, based on the result of pre-test and post-test, descriptively, there was an improvement in students' learning outcome (knowledge). The following was an analysis of pre-test and post-test results data. Normality test on pre-test and post-test results showed that the data was not normally distributed, this was indicated by the SPSS output of the normality test by kolmogorov-smirnov with a significant level of 0.5 .

Because the learning outcome data was not normally distributed, then the analysis was continued with nonparametric statistics to test whether or not there was an increase in learning outcomes from pre-test and post-test. The test used was wicoxon signed ranks test. The result of data analysis showed that post-test result was better than pre-test result, so it can be concluded that there was an increase in learning outcomes before and after using interactive tangram game media in the learning process. 


\section{Dissemination Stage}

Dissemination of the integrative tangram game media was conducted for all study groups of Geometry and Measurement courses.

Tangram interactive game media was developed with macromedia flash software through five stages, which were defining, design, development, and dissemination. After going through those four stages, a valid integrative tangram game media was obtained. Its validity was shown by the score given by material expert and media expert, which was 3.09 and it was included in the good category. In addition, it was also proven at the time of field trials, the results of geometry and measurement learning on the plane shape material of students of Department of Primary School Teacher Education had improved. Moreover, inspirational characters measured through the activity process and student work in the form of student worksheets showed a good average results (2.84) Characteristics of developed integrative tangram game media was an instructional media that was intended for students of the Department of Primary School Teacher Education that can be used in geometry and measurements lecturers, particularly in plane shape material. The components containing in integrative tangram game media include introduction, material, instructional examples, exercises, and tasks.

Introduction component contained the tangram definition and how to make tangram. Based on this introduction, the students may generally understand tangram media. The material component consisted of learning theory by Van Hiele, geometry definition and curriculum in elementary school about the contents standard that was in accordance with the latest the regulation of ministry of education and culture of 2016. From the material component, students acquired knowledge about geometry, learning theory in geometry as well as material coverage of geometry and measurement in elementary school that was in accordance with applicable curriculum.

Instructional example component contained student worksheet used to have a group discussion (it can also be used to learn independently) and do some activities, for example, arranging tangram into several new plane shapes (triangle, square, rectangle, parallelogram, isosceles trapezoid and right-angled trapezoid). The process of forming new shapes form seven plane shapes in tangram is called as tangramming (Bohning \& Althause, 1997, p. 239). According to Bohning \& Althause (1997, p. 239-240), having experience with tangram has several advantages: improving children vocabulary in geometry, recognizing shapes, classifying shapes and finding relationships between the seven plane shapes in the tangram. Through this instructional example component, the students may obtain experience on geometry and measurement, especially on the plane shape material using tangram media.

The next component was the exercises. There were two exercises to be given to the students. The exercises on geometry and measurement material on plane shapes were adapted to basic competencies in the early and high class. From this component, the students may obtain an idea to make exercises by referring to the presented basic competencies. The first exercise was about identifying and grouping plane shapes, from this exercise, it was expected that students will understand similarity and symmetry on the plane shape. The second exercise was about the measurement material, which was the area on a plane shape. After working on this second exercise, the students were expected to have awareness about proportion of the area of each plane shape forming a tangram. This activity was undertaken by comparing the shape and total area of the whole tangram (Haciomeroglu \& Haciomeroglu, 2007, p. 67).

The last component was a task containing independent tasks that can be carried out by students to make an instructional activity of geometry and measurement material on plane shape for Elementary School. The students were assigned to adapt worksheets presenting in integrative tangram game media for learning geometry in elementary school. From the observation on 
lecturing process and portfolio of student task result, it was found the average score of 2.8 (good category). Therefore, the inspirational character implanted through lecture by utilizing integrative tangram game media may inspire students in learning geometry. It was seen from element of novelty, usefulness, and creativity of the student.

Integrative tangram game media is one of the media that can also be used for independent learning. This game is created to avoid the boredom that may be faced by the students. It also has benefit in the learning process as supported by Carifa \& Gooding (2011: 372), "Educational games stimulate and support critical thinking and encourage creativity, collaboration, networking, and problem solving among peers."

\section{Results and Recommendations}

Based on the stages of process of media development, research results, data analysis and discussion, it can be concluded:

1. The process of interactive tangram game media development in the learning of plane geometry and measurement for the students of Department of Primary School Teacher Education, Faculty of Teacher Training and Education, Universitas Negeri Semarang, was performed through $4 \mathrm{D}$ development stage. Therefore, it may produce interactive tangram game media, which had special characteristics that was Van Hiele Theory based Interactive tangram game media. It was an instructional media for students of the Department of Primary School Teacher Education that can be used in geometry and measurement lectures particularly for plane shape material and four components presented in interactive tangram game media, including introduction, material, examples, exercises and tasks.

2. Interactive tangram game media in the learning of plane geometry and measurement for students of Department of Primary School Teacher Education, Faculty of Teacher Training and Education, UNNES constitutes a valid instructional media. It was proven by good category $(3,09)$ given by media expert and material expert to the tangram interactive game media. It was also proven, the conceptual understanding of geometry and measurement learning on the plane shape material of students of Department of Primary School Teacher Education had improved.

Suggestions from the developments of this tangram interactive game media are:

1. Further study about Van Hiele Theory is required directly in geometry learning for both elementary and college level, especially in the Department of Primary School Teacher Education.

2. The resolution of laptop screen affects the display of tangram interactive game media, so it is necessary to perform adjustment before tangram interactive game media is used in android with smaller screens. 


\section{References}

i. $\quad$ Chang, K., Sung, Y. \& Lin, S., 2007. Developing Geometry Thinking through Multimedia Learning activities. Computers in Human Behaviour, Volume 23, pp. 2221-2229.

ii. $\quad$ dikti, D. d., 2004. Peningkatan Kualitas Pembelajaran. Jakarta: Depdiknas.

iii. Gerry, B., Althause \& Kosack, J., 1997. Using Tangrams to Teach Geometry to Young children. Early Childhood Educational Journal, Volume 24, p. 24.

iv. Guney, H., Haciomeroglu \& Selcuk, E., 2007. Elementary Preservice Teachers' Experiences with Tangrams. Proceedings of the 29th annual meeting of the North American Chapter of the International Group for the Psychology of Mathematics Education, Stateline (Lake Tahoe). Reno, University of Nevada.

v. Joanna, M., Lester \& Frank, K., 1998. Mathematics for Elementary Teachers via Problem Solving. s.l.:Prentice Hall Inc.

vi. John, W. \& De, A. V., 2007. Elementary and Middle School Mathematics Teaching Developmentally. s.l.:Pearson Education Inc.

vii. Judith, S., York, A. \& White, S., 1997. Strategies for Teaching Young Children. Englewood Cliefs, New Jersey: Prentice-Hall Inc.

viii. Linda, C. \& Jeniszweski, G. H., 2011. Using Games to Provide Interactive Perioperative Education. AORN Journal, 94(4).

ix. $\quad$ Maman, R., 2015. Pendekatan Penelitian Kuantitatif, Kualitatif, Mixed PTK dan R\&D. Yigyakarta: Magnum Pustaka Utama.

x. Pitadjeng, 2015. Pembelajaran Matematika yang Menyenangkan. Yogyakarta: Graha Ilmu.

xi. $\quad$ Ruseffendi, 1992. Pendidikan Matematika III. Jakarta: Depdikbud.

xii. Topas, V., 2011. An Analysis of the Turkish New Elementary Mathematics Curriculum and Textbooks in terms of the Presentation of Geometric Concepts.. Centre in Innovation Mathematics Teaching Journal.

xiii. Z Zilkova, K., Gucaga, J. \& Kopacova, J., 2015. (Mis)Conceptions About Geometric Shapes In PreService Primary Teachers. Acta Didactica Napocensia,, pp. 2065-1430. 